\title{
Electroconvulsive shock induced amnesia and recovery ${ }^{1}$
}

\author{
ANNE GELLER AND M. E. JARVIK \\ ALBERT EINSTEIN COLLEGE OF MEDICINE, NEW YORK
}

Recovery from electroconvulsive shock (ECS) induced amnesia in mice did not occur with time alone or with multipie trials in a stepthrough apparatus, although attempts were made to increase the probability of such recovery. Subjects receiving foot shock (FS) and ECS always show significantly higher latencies than unshocked controls and this difference can be increased using a threshold FS after extinction.

There has been considerable controversy in the literature as to whether ECS can induce retrograde amnesia (RA) at all (Lewis \& Maher, 1965) and, if it does, whether it is effective given more than 10 sec from the training trial (Chorover, 1965), and recently, whether there is recovery from this apparent amnesia. Zinkin \& Miller (1967) found that in a step-down apparatus with rats, recovery from amnesia observed at $24 \mathrm{~h}$ occurred if the animals were given additional reinforced trials at 48 and 72 h. Luttges \& McGaugh (1967) found this not to be true for mice using a step-through apparatus.

The period of RA in man following concussion frequently shrinks spontaneously during recovery (Russell \& Nathan, 1946) although there is usually an irreducible few seconds of amnesia. The recovery observed by Zinkin and Miller in rats following ECS may be analogous. It seemed reasonable that the probability of recovery might be increased if the interval between training and ECS were extended and if the animals were allowed to explore the apparatus extensively prior to training. It also seemed possible that a threshold FS might reveal "latent learning" in apparently amnestic animals.

\section{EXPERIMENT 1}

\section{Subjects}

The Ss were 138 naive CF1 female mice, 6-8 weeks old, and were housed eight to a cage with ad lib access to food and water.

\section{Apparafus and Procedure}

The step-through apparatus was that described by Jarvik \& Kopp (1967) and consisted of a trough shaped two compartment box in which the animal could receive a $500 \mathrm{~mA}$ FS for stepping from a small lighted compartment to a larger darkened one. The Ss escaped from the FS back to the light compartment from which they were removed. Retest trials were run with the same procedure except no shock was used and the Ss, if they stepped through, were removed from the black compartment.

Through transcorneal electrodes, ECS was administered $20 \mathrm{sec}$ after the training trial. A Hans electroshock apparatus (2-C) was used with convulsive shock of $20 \mathrm{~mA}$ for .2 sec.

Subjects were discarded from the experiment for the following reasons: (1) latency greater than $60 \mathrm{sec}$ on training trial (7 Ss); (2) fallure to have full tonic clonic convulsions (2 Ss); (3) death (2 Ss).

The Ss were divided into the following groups: Group C (N=10) received no treatment. They were run in the apparatus on the training day and at 24, 48, 72, and $168 \mathrm{~h}$. All other Ss recelved FS on the training day. Half the Ss (A groups) recelved no further treatment; the other half (B groups) received ECS 20 sec after the punishing shock. The Ss were then subdivided according to their testing schedule. Group 1A $(N=15)$ and $1 B(N=13)$ were tested at 24 . 48, 72, and $168 \mathrm{~h}$. Group $2 \mathrm{~A}(\mathrm{~N}=15)$ and $2 \mathrm{~B}(\mathrm{~N}=13)$ were tested at 48,72 , and $168 \mathrm{~h}$. Group $3 A(N=14)$ and $3 B(N=13)$ were tested at 72 and $168 \mathrm{~h}$. Group $4 A(N=16)$ and $4 B(N=16)$ were tested at six weeks. Results

The usual criterion of retention in a step-through experiment is the length of time $S$ remains in the front compartment. In this experiment all the A groups (FS-no ECS) had a median of $>300$ sec (arbitrary cutoff) on first retest except $4 A$ (median 200) and all the B groups (FS-ECS) had medians less than 60 on the first retest. At all time intervals, the FS group had a higher median latency than its partner ECS group, and this was significant at the $<.005$ level (Wilcoxon et al, 1963) for all test pairs at all time intervals. Furthermore, there was a tendency for the median latencies for all groups to decline with successive trials, which might be expected since any animal that steps through and does not get shocked has an extinction trial. Differences for Group 1B between the first trial $(24 \mathrm{~h})$ and the fourth trial $(168 \mathrm{~h})$ are significant at $<.005$ level. No significant differences were observed between the first trials of IB (24 h), 2B (48 h), 3B (72 h), and 4B (6 weeks). Significant differences at the $<.005$ level were also noted between the FS-ECS groups and the nonshocked controls for all time intervals for which they were tested.

For the nonshocked control groups, steady stepthrough latencies were obtained for all trials and individual fluctuations in latency did not exceed $16 \mathrm{sec}$. For the FS-ECS groups, 69\% showed fluctuations $>20$ sec and of these, $26 \%$ showed an increase of $>20 \mathrm{sec}$ of Trial 2, 3, or 4 over Trial 1. 


\section{EXPERIMENT 2}

This experiment examined the effects of preliminary exposure to the apparatus.

\section{Subjects}

The Ss were 50 naive $C F 1$ female mice, 6-8 weeks old. Apparatus and Procedure

The apparatus was the same as that used in Experiment 1. All animals were given 5 min of exposure to the apparatus daily for four days. They were then divided into the following groups: Group $1(\mathrm{~N}=17$; control unshocked) were run in the apparatus on Days $5,6,7,8$ and removed as soon as they had stepped into the black compartment. Group $2(\mathrm{~N}=16)$ received a $500 \mathrm{~mA}$ FS on stepping through on Day 5 and were tested on Days 6, 7, and 8. Group $3(\mathrm{~N}=17)$ were treated as Group 2, but were given transcorneal ECS 20 sec after the shocked trial on Day 5.

Results

Differences between Group 2 (FS) and Group 3 (FS-ECS) were significant at the $<.005$ level for Days 6, 7, and 8 . Median latencies of both groups were lower than in Experiment 1. The FS-ECS group again showed a decline in latencies over the three trials. Medians for the NS control and the FS-ECS group were 7.2 and $11.5 \mathrm{sec}$, respectively, compared with FS median of $202 \mathrm{sec}$. Differences between the control and ECS groups were significant at the $<.025$ level.

\section{EXPERIMENT 3}

\section{Subjects}

The Ss were 34 animals from Groups 2 and 3 of Experiment 2.

\section{Apparatus and Procedure}

The apparatus was the same as that used in Experiments 1 and 2. The Ss were allowed to explore the apparatus without shock $5 \mathrm{~min}$ daily for four days after the conclusion of Expariment 2. The median step-through latency for Group 1 was 5.7 and for Group 34.1 on Day 4. The difference was not significant. On Day 5 all Ss received a threshold FS (50 $\mathrm{mA}$ ) on stepping into the black compartment.

Results

Median latency on Day 6 was $27.0 \mathrm{sec}$ for Group 1 and $58,3 \mathrm{sec}$ for Group 3 . This was significant at the $<.005$ level.

\section{Discussion}

Using mice in a step-through apparatus there does not seem to be any overall evidence for recovery of the ECS induced amnesia either with time or with multiple trials, even under conditions designed to increase the probability of such recovery. Three possible explanations for the recovery observed by Zinkin \& Miller (1967) occur: (1) ECS does not induce a true RA but has some nonspecific "fear reducing" motor activity effects which dissipate with time; (2) ECS does induce true $R A$ and the recovery is analogous to that seen in postconcussion $\mathrm{RA}$; and (3) that ECS induces only a partial amnesia (i.e., some aversive conditioning remains) and this can be reinforced or extinguished over several trials depending upon the experimental technique.

To avoid the latter explanation, recovery must be shown to occur with time alone. If this is found to be the case with rats and not mice, then one might assume that the fear reducing or motor activity effects of ECS are permanent in one species and transitory in another. Or alternatively, there may be shrinkage of RA with time but the time relations vary among species. Perhaps in the mouse, a smaller animal with a higher rate of metabolism, potential recovery is essentially completed at $24 \mathrm{~h}$ so that no further recovery can be demonstrated at longer time intervals.

\section{References}

CHOROVER, S. L., \& SCHILLER, P. H. Short term retrograde amnesia in rats. $J$. comp. physiol. Psychol., 1965, 59, 73-78.

JARVIK, M. E., \& KOPP, R. An improved one-trial passive avoidance learning situation. Psychol. Rpts., 1967, 21, 221-224.

LEWIS, D. J., \& MAHER, B. A. Neural consolidation and electroconvulsive shock. Psychol. Rev., 1965, 72, 225-239.

LUTTGES, M. W., \& McGAUGH, J. L. Permanence of retrograde amnesia produced by ECS. Science, 1967, 156, 408-410.

RUSSELL, W. R., \& NATHAN, P. W. Traumatic amnesia. Brain, 1946, 69, 280-300.

WILCOXON, F., KATTI, S. K., \& WILCOX, R. A. Critical values and probability levels for the Wilcoxon Rank Sum Test and the Wilcoxon Rank Test. Lederle Laboratories Division, American Cyanamid Co. August, 1963.

ZINKIN, S., \& MILLER, A. J. Recovery of memory after amnesia induced by ECS. Science, 1967, 155, 102-104.

\section{Notes}

1. Fuller details on this experiment can be obtained from Dr. Geller on request.

2. This work was supported by U. S. Public Health Service Grants MH 01225 . MH 05319 and STI MH 6418. 